\title{
DESAIN SISTEM MOBILE WEB STORE MENGGUNAKAN CODEIGNITER, MYSQL, DAN JQUERY MOBILE
}

\author{
Suhartono \\ Staf Pengajar Jurusan Teknik Elektro Fakultas Teknik Uiversitas Negeri Makassar
}

E-mail: suhartonoft@unm.ac.id

\begin{abstract}
Abstrak
Tujuan penelitian ini adalah untuk membangun sistem mobile web store menggunakan code-igniter, mysql dan jquery mobile, untuk membantu dalam mendesain sistem penjualan yang berbasis web mobile dan client-server mobile. Pembuatan sistem terdiri dari client dan server dimana dengan sistem ini dapat memonitoring keadaan penjualan. Metode yang digunakan adalah System Development Life CycleSDLC. Tahapan dalam membangun sistem meliputi mengidentifikasi kebutuhan, membangun prototipe, megevaluasi prototipe, mengkodekan sistem, menguji sistem, mengevaluasi sistem, dan menggunakan sistem. Hasil dari penelitian ini adalah sebuah sistem mobile web store yang menggunakan bahasa pemrograman web PHP serta framework CodeIgniter, MySQL, dan jQuery Mobile yang dapat mempermudah promosi barang dan pengaturan barang lebih baik dan efesien.
\end{abstract}

Kata Kunci : sistem mobile, penjualan, PHP, framework, promosi

\begin{abstract}
The design of the mobile web strore system using Codedeigniter, mysql and journey mobile. The purpose of this research is to build a mobile web store system using code-Igniter, mysql and jquery mobile, to assist in designing a mobile web-based sales system and client-server mobile. The process of making the system consists of client and server where the system is able to monitor the state of the sales. It employs the System Development Life CycleSDLC. The stages in the building system includes identifying needs, building prototypes, evaluating a prototype, coding systems, testing systems, evaluating the system, and using the system. The result of this study is a mobile system that uses a web store web programming language and framework CodeIgniter PHP, MySQL, and jQuery Mobile that can facilitate the promotion and make better goods setting efficiently.
\end{abstract}

Keywords: mobile system, sales, PHP, framework, promotion

\section{Pendahuluan}

Perkembangan teknologi informasi yang semakin hari semakin pesat mendorong manusia untuk berinovasi menciptakan sesuatu yang baru, untuk mempermudah pekerjaan dan memenuhi kebutuhan hidupnya. Hal tersebut berdampak pada gaya hidup dan perilaku kebanyakan orang, yang menginginkan kebutuhan informasi yang lebih cepat. Untuk mendapatkan informasi secara mudah dan cepat, banyak orang menggunakan koneksi internet sebagai salah satu solusinya. Koneksi internet tersebut memungkinkan banyak website dijelajahi oleh pengguna sebagai sumber informasi (Wardani, 2012).

Seiring dengan pesatnya perkembangan teknologi informasi, pesat pula populasi konsumennya, terutama teknologi web dan mobile. Atas nama pasar, tidak jarang para produsen teknologi memadukan kedua teknologi tersebut (Riyanto, 2013). Teknologi website sebagai sebuah media yang menyediakan banyak informasi, membuat penggunannya semakin ingin menjelajah berbagai situs dengan lebih praktis dan efisien. Salah satu cara yang dilakukan yaitu menjelajah 
situs melalui telepon genggam. Sesuai dengan perkembanganya, website sekarang ini tidak hanya bisa diakses melalui personal computer $(P C)$ saja, tetapi juga dapat diakses melalui telepon genggam, yang biasa disebut mobile web. Dengan sistem ini dapat memungkinkan pengguna mengakses informasi tanpa batasan waktu dan tempat. Banyaknya pengguna perangkat mobile saat ini, membuat mobile web semakin banyak digunakan dan dikembangkan lagi (Wardani, 2012).

Menurut Riyanto (2013) beberapa tahun yang lalu, pembuatan situs web lebih difokuskan kepada penggunaan PC atau laptop daripada pengguna perangkat mobile. Saat ini, hampir semua situs web populer, tidak terkecuali situs penjualan online, menyediakan situs web versi mobile. Setidaknya ada empat alasan dibutuhkannya situs web versi mobile. Pengguna perangkat mobile yang sangat besar dan murahnya biaya akses data, secara tidak langsung meningkatkan pula pengunjung situs web melalui perangkat mobile. Selain itu, situs web versi mobile memiliki daya tarik tersendiri bagi pengunjung karena lebih cepat aksesnya. Mengingat perangkat mobile mempunyai keterbatasan sumber daya, terutama di bagian pemroses dan memori, situs web yang ringan dan cepat aksesnya tentu lebih disukai. Selain itu, menggunakan situs web versi mobile lebih nyaman. Desain sederhana membuatnya mudah dioperasikan dan lebih hemat biaya akses datanya. Dengan desain sederhana tentunya ukuran file-file penyusunnya relatif kecil karena tidak memerlukan desain berlebih yang biasanya melibatkan file gambar atau animasi. Sistem web versi mobile juga jauh lebih murah untuk dikembangkan dan bisa berjalan dimana saja (lintas platform). Selain itu, karena mobilitas yang tinggi dan waktu yang tidak memungkinkan untuk selalu menggunakan PC, kebutuhan untuk selalu menggunakan web setiap saat, kapanpun, dimanapun, dan setiap saat dapat diakses.

Ada beberapa manfaat dalam mengembangkan situs web versi mobile diantaranya adalah CodeIgniter dan jQuery Mobile. CodeIgniter atau CI adalah sebuah framework yang digunakan untuk membuat situs web yang disusun dari bahasa pemrogamman PHP. Di dalam CI terdapat beberapa macam kelas dalam bentuk pustaka dan helper, yang dapat digunakan sebagai tool untuk mengembangkan situs web.
Sedangkan jQuery mobile adalah web framework yang dioptimasi untuk mendesain aplikasi yang akan dijalankan pada perangkat bergerak (mobile device), seperti smartphone dan tablet (Nugroho, 2008).

Kelebihan mobile internet yang memperbolehkan pengguna melakukan ketika mereka sedang melakukan kegiatan lain, seperti berbelanja atau dalam perjalanan, akan menambah jumlah pengguna mobile internet sampai empat kali lipat dari pengguna internet dari personal computer. Hal ini menunjukkan bahwa era ini adalah waktu yang tepat dalam mengembangkan strategi mobile internet, dan mengembangkan website yang berorientasi pada mobile. (Jogianto, 2005)

Tujuan studi ini adalah membangun sistem mobile web store menggunakan codeigniter,mysql dan jquery mobile, untuk membantu dalam mendesain sistem penjualan yang berbasis web mobile dan client-server mobile. Pembuatan sistem terdiri dari client dan server dimana dengan memanfaatkan sistem ini dapat memonitoring keadaan penjualan. Metode yang digunakan dalam penelitian ini adalah System Development Life CycleSDLC.

\section{Landasan Teori}

\section{Aplikasi}

Aplikasi adalah satu unit perangkat lunak yang dibuat untuk melayani kebutuhan akan beberapa aktivitas. Misalnya termasuk perangkat lunak perusahaan, software akuntansi, perkantoran, grafis perangkat lunak dan pemutar media. Dapat disimpulkan bahwa aplikasi merupakan software yang berfungsi untuk melakukan berbagai bentuk pekerjaan atau tugas-tugas tertentu seperti penerapan, penggunaan dan penambahan data (Jogianto, 2005).

Program aplikasi merupakan program siap pakai. Program yang direka untuk melaksanakan suatu fungsi bagi pengguna atau aplikasi yang lain. Contoh-contoh aplikasi ialah program pemroses kata dan Web Browser. Aplikasi akan menggunakan sistem operasi (OS) komputer dan aplikasi yang lainnya yang mendukung (Winarto, 2014).

Klasifikasi aplikasi dapat dibagi menjadi 2 (dua) yaitu: aplikasi software spesialis, program dengan dokumentasi tergabung yang dirancang 
untuk menjalankan tugas tertentu dan aplikasi paket, dengan dokumentasi tergabung yang diranncang untuk jenis masalah tertentu. (Paranginan, 2006)

\section{Mobile}

Perangkat mobile memiliki banyak jenis dalam hal ukuran, desain dan layout, tetapi mereka memiliki kesamaan karakteristik yang sangat berbeda dari sistem dekstop, yaitu antara lain ukuran yang kecil, memori yang terbatas, daya proses yang terbatas, mengkomsumsi daya yang rendah, kuat dan dapat diandalkan dan konektivitas yang terbatas (Riyanto, 2013.

\section{Teori Mobile Web Application}

Mobile web application adalah aplikasi mobile yang tidak perlu di-install atau di-compile pada device. Mobile web application menggunakan XHTML, CSS, dan JavaScript, Mobile Web Application dapat memberikan pengalaman seperti memakai aplikasi pada pengguna ketika menjalankanya di Mobile Web Browser.Web Application memungkinkan pengguna untuk berinteraksi dengan konten dalam kondisi realtime, dimana klik atau touch melakukan aksi di dalam tampilann saat ini (Riyanto, 2013.

Kelebihan Mobile Web Application mudah dibuat dengann HTML dasar, CSS dan JavaScript, mudah untuk disesuakan dengan beberapa telepon selular dan menawarkan pengalaman yang lebih baik dan desain yang lebih kaya pada pengguna dan konten dapat diakses oleh semua Mobile Web Browser (Paraningan, 2006).

Kekurangan Mobile Web Application adalah pengalaman yang optimal mungkin tersedia di beberapa telepon selular, banyak rintangan untuk mendukung beberpa telepon selular dan tidak semua Mobile Web Application mendukung fitur mode offline, location lookup, filesystem acces dan kamera (Riyanto, 2013).

\section{Konsep Dasar Analisis Sistem}

Analisis sistem dapat didefenisikan sebagai penguraian dari suatu sistem informasi yang utuh ke dalam bagian-bagian komponennya dengan maksud untuk mengidentifikasi dan mengevaluasi permasalahan-permasalahan, kesempatan-kesempatan, hambatan-hambatan yanng terjadi dan kebutuhan yang diharapkan sehingga dapat diusulkann perbaikannperbaikannya. Tujuan utamanya adalah untuk memahami sistem dan masalah yang ada, untuk menguraikan kebutuhan informasi dan untuk menetapkan prioritas pekerjaan sistem selanjutnya (Jogiyanto, 2005).

\section{Perancangan Sistem}

Hal yang paling dominan ketika perancangan suatu aplikasi dilakukan adalah memodelkan kebutuhan pemakai. Ada banyak cara untuk memodelkan aplikasi sebagaimana banyak cara yang digunakan oleh seorang arsitek untuk membangun sebuah rumah. Pada dasarnya pemodelan tersebut merupakan kombinasi antara perangkat lunak dan perangkat keras yang digunakan (Raharjo, 2012).

\section{Sistem Database MySQL}

Menurut Firmansyah Database Mysql merupakan sekelumpulan item-item yang saling terekait satu denga yang lainya yang diorganisasikan berdasarkan skema atau struktur tertentu,tersimpan dalam sebuah storage dan degan bantuan software dapat dilakukan manipulasi sesuai dega kebutuhan (Nugroho, 2008).

\section{Teori Alat Penelitian}

Pada pembangunan Mobile Web Sotre dengan CodeIgniter,MySQL dan jQuery Mobile ini digunakan bahasa pemrogamman $\mathrm{Php}$ dan MySQL, juga menggunakan CodeIgniter atau CI yang berfungsi sebagai framework untuk mengembangkan situs web versi mobile. Selain CodeIgniter, jQuery Mobile juga digunakan untuk membangun webmobile ini (Nugroho, 2013).

\section{Codelgniter}

Codelgniter adalah aplikasi open source yang berupa framework dengan model MVC (Model, View, Controller) untuk membangun website dinamis dengan menggunakan PHP. Codelgniter memudahkan developer untuk membuat aplikasi web dengan cepat dan mudah dibandingkan dengan membuatnya dari awal. Codelgniter dirilis pertama kali pada 28 Februari 2006. Versi stabil terakhir adalah versi 2.1.3 (Basuki, 2014).. 


\section{DINAMIKA Jurnal Ilmiah Teknik Mesin}

\section{Framework}

Framework secara sederhana dapat diartikan kumpulan dari fungsi-fungsi atau prosedurprosedur dan class-class untuk tujuann tertentu yang sudah siap digunakan sehingga bisa lebih mempermudah dan mempercepat pekerjaan seorang programmer, tanpa harus membuat fungsi atau class dari awal (Basuki, 2014).

\section{Design Patern:MVC (Model, View, Controller)}

Model View Controller merupakan suatu konsep yang cukup populer dalam pembangunan aplikasi web, berawal pada bahasa pemrograman Small Talk, MVC memisahkan pengembangan aplikasi berdasarkan komponen utama yang membangun sebuah aplikasi seperti manipulasi data, userinterface, dan bagian yang menjadi kontrol aplikasi (Nugroho, 2013).

Codeligniter atau CI adalah suatu framework yang digunakan untuk membuat situs web yang disusun dari bahasa pemrogammann PHP. Di dalam CI terdapat beberapa macam kelas dalam benntuk pustaka dan helper, yang dapat digunakan sebagai tool untuk mengembangkan situs web (Riyanto, 2013).

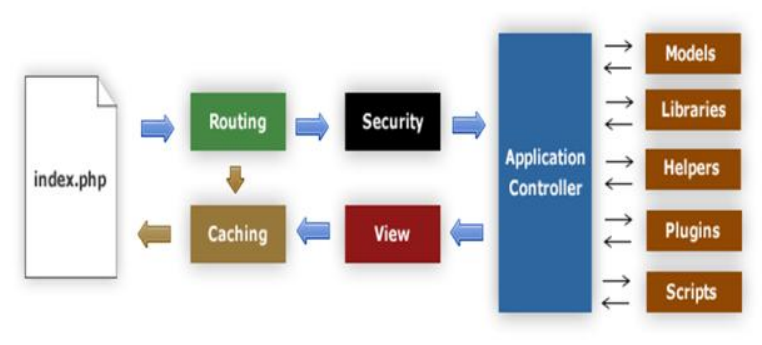

Gambar 1 Struktur Flow CodeIgniter (Riyanto, 2013)

\section{jQuery Mobile}

jQuery Mobile adalah web framework yang dioptimasi untuk mendesain aplikasi yang akan dijalankan pada perangkat bergerak (mobile device), seperti smarthphone dan tablet (Riyanto, 2013).

\section{Dreamweaver}

Dreamweaver adalah software aplikasi yang digunakan sebagai HTML editor professional untuk mendisain web secara virtual (Wahan Komputer. 2013).

\section{Metodologi Penelitian}

Dalam penelitian ini penulis menggunakan model prosedural karena dianggap cocok dengan tujuan yang ingin dicapai yaitu menghasilkan produk dan menguji kelayakan produk yang dihasilkan dimana untuk mencapai tujuan tersebut harus melalui langkah-langkah tertentu yang harus diikuti untuk menghasilkan produk tertentu. pada penelitian ini akan menghasilkan suatu produk sistem Mobile Web Store.

\section{Metode Pengembangan Sistem}

Adapun metode pengembangan dalam membangun sistem ini yaitu menggunakan metode pengembangan SDLC. Metode siklus hidup pengembangan sistem atau system development life cycle mempunyai beberapa tahapan sesuai dengan namanya, SDLC dimulai dari suatu tahapan sampai tahapan terakhir dan kembali lagi ketahapan awal membentuk suatu siklus atau daur hidup.

\section{Diagram Konteks}

Diagram konteks merupakan aliran yang memodelkan hubungan antara sistem dengan entitas. Selain itu diagram konteks merupakan diagram yang paling awal yang terdiri dari sutau proses data dan menggambarkan ruang lingkup suatu sistem secara garis besarnya. Aliran dalam diagram konteks memodelkan masukan ke sistem dan keluaran dari sistem.

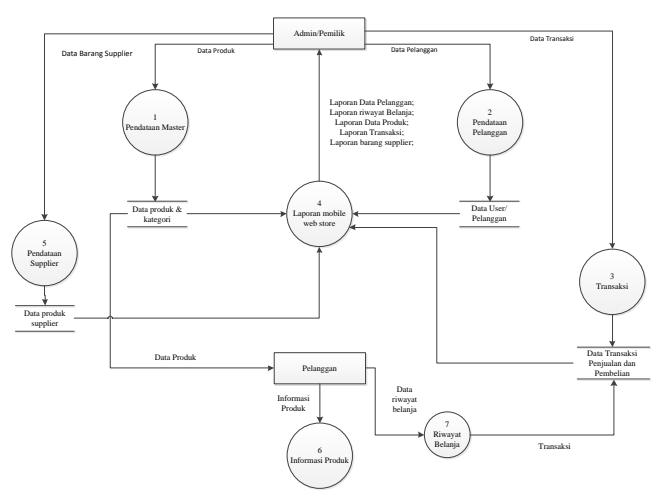

Gambar 4 Data flow diagram Level 1 


\section{DINAMIKA Jurnal IImiah Teknik Mesin}

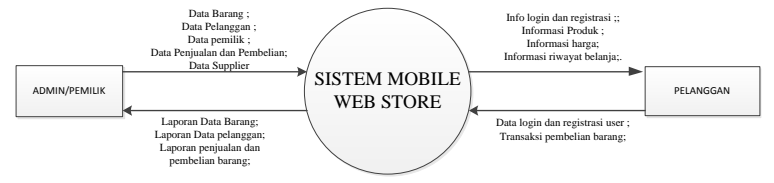

Gambar 3 Diagram Konteks (DFD Context)

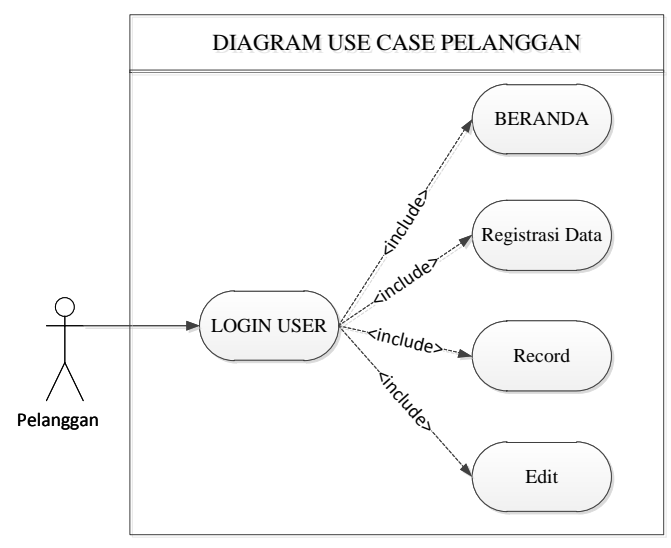

Gambar 4 Diagram UML Use Case/UML Use Case Diagram

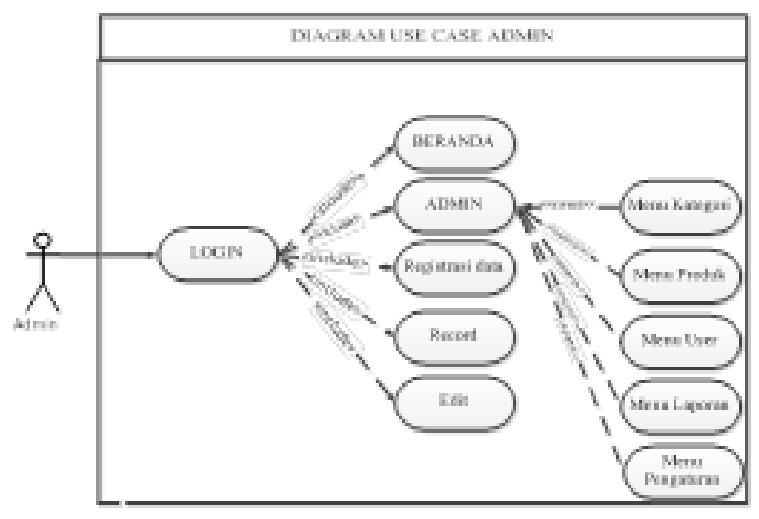

Gambar 6 Diagram Use Case Pelanggan

\section{Pengujian Sistem}

Pengujian sistem dimaksud adalahproses menilai apakah yang dirancang telah sesuai dengan yang diharapkan dan dilakukan dengan tujuan mengevaluasi keunggulan dan kelemahan terhadap sesuatu yang diuji (kualitas produk). Proses pengujian ini dilakukan secara berkala dengan mengevaluasi input dan otput yang dihasilkan oleh sistem.

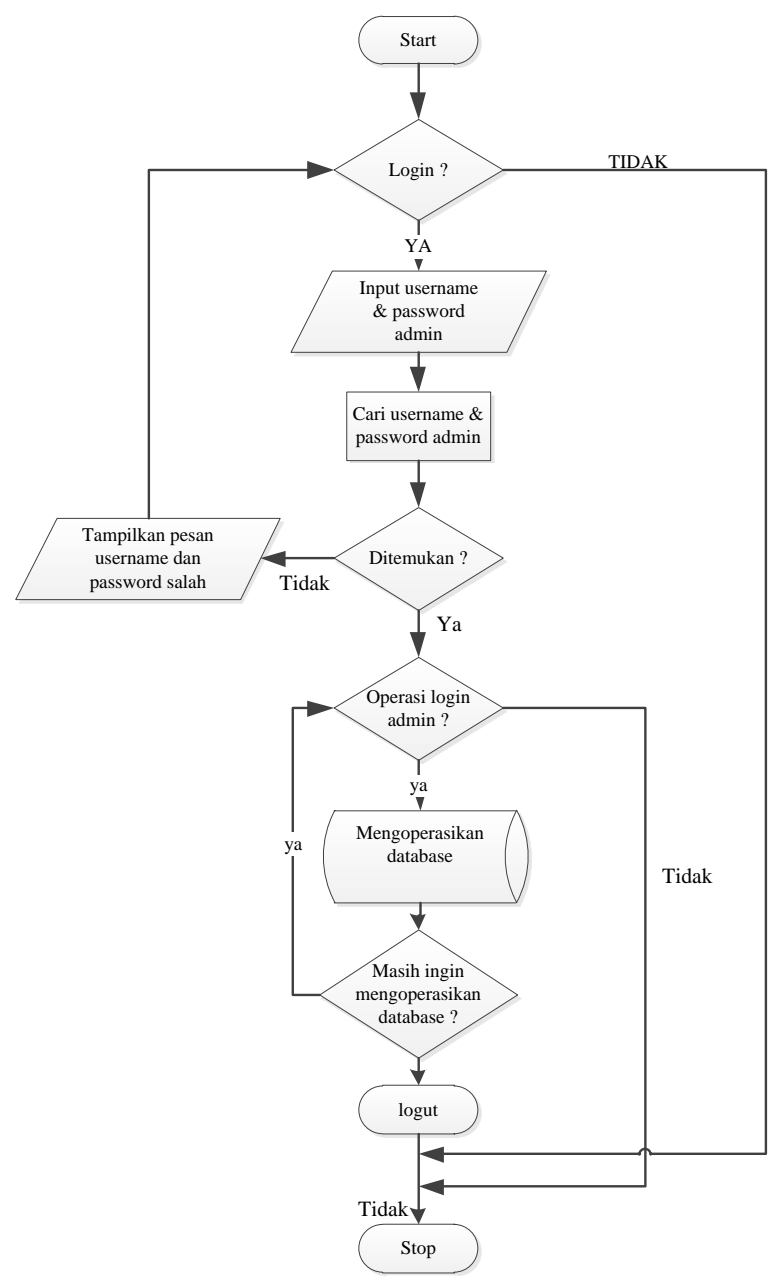

Gambar 7 Flowchart Login Admin

\section{Rencana Pengujian}

Untuk menguji program aplikasi yang dirancang, penulis menggunakan metode Black Box. Pengujian black-box berfokus pada persyaratan fungsional perangkat lunak. Pengujian ini memungkinkan analis sistem memperoleh kumpulan kondisi input yg akan mengerjakan seluruh keperluan fungsional program.Sistem yang dibuat harus bebas dari kesalahan yang mungkin dapat terjadi 
Tujuan metode ini mencari kesalahan pada fungsi yang salah atau hilang, kesalahan pada interface, kesalahan pada struktur data atau akses database, kesalahan performansi dan kesalahan inisialisasi dan tujuan akhir

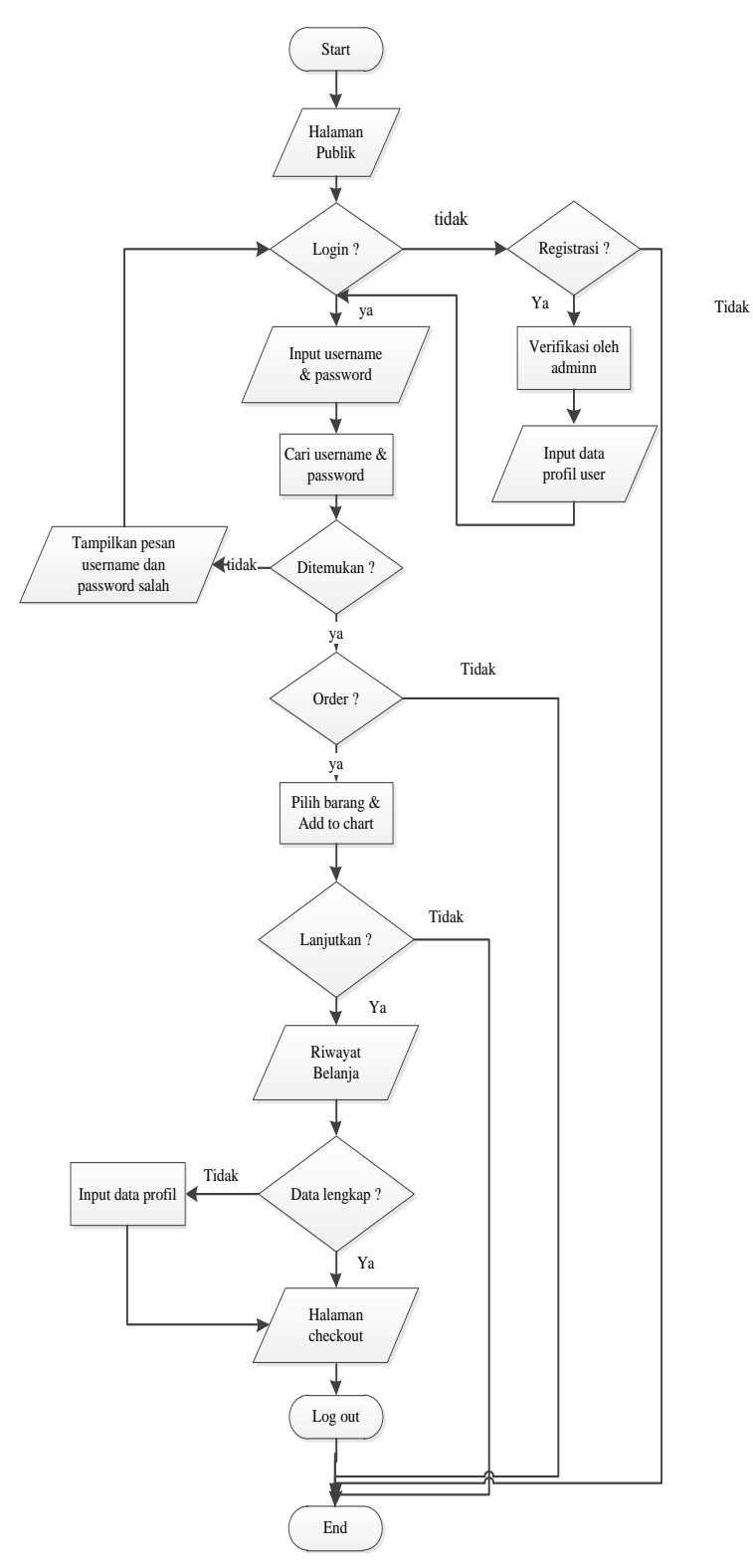

Gambar 8 Flowchart Login User

\section{Hasil}

Sistem mobile web store ini merupakan sistem yang dibangung dengan menggunkan framework CodeIgniter dan jQuery mobile serta MySQL sebagai databasenya. Framework CodeIgniter berfungsi untuk mengatur proses berjalannya sistem yaitu bagaimana saat user mengakses sistem yang dioperasikan menggunakan MVC (Model, View, Controller). Model pada codeigniter menangani langsung database dari sistem, untuk View pada codeigniter adalah untuk menampilkan informasi yang ditampilkan kepada user melalui browser, dan Controller pada codeigniter merupakan "business logic" bertugas sebagai jembatan antara Model dan View. Sedangkan untuk framework jQuery Mobile adalah framework yang menangani desain tampilan yang akan ditampilkan ke $u s e r$.

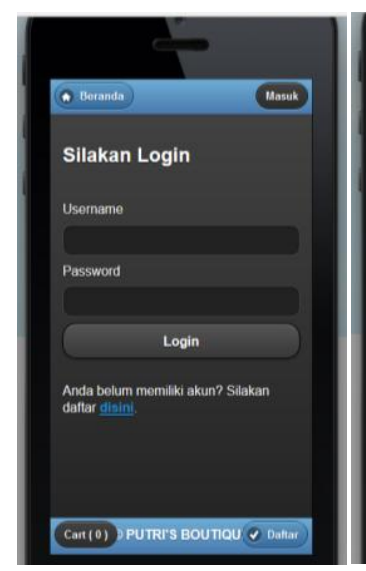

(a)

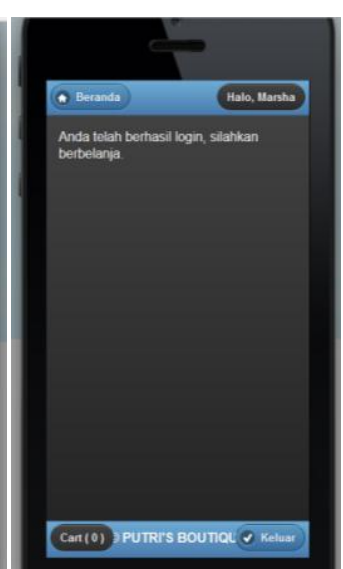

(b)
Gambar 9 (a) Tampilan Menu Login User (versi mobile) (b). Tampilan Menu Login User berhasil(versi mobile)

Sistem ini memiliki 2 level user, yaitu level Admin dan level Pelanggan. Level Admin digunakan untuk melakukan manipulasi data (insert,update, dan delete) seluruh data yang ada.seperti data katagori, data produk dan data user. Admin juga bertugas untuk menangani pemesanan barang dari user, dan pembuatan laporan riwayat belanja masing-masing user pelanggan. Halaman ini hanya dapat diakses oleh login user sebagai Admin, user yang login sebagai pelanggan tidak mempunyai hak akses 
seperti login user Admin. Sedangkan untuk level pelanggan merupakan level user yang digunakan oleh user pelanggan yang memiliki hak ases untuk melakukan pemesanan produk, mengedit identitas user, dan melihat daftar riwayat belanjanya. User yang tidak memiliki akun pada sistem ini atau belum melakukan registrasi pada sistem mobile web store ini tidak dapat melakukan pemesanan barang. User yang tidak melakukan login, hanya dapat melihat-ligat daftar produk yang ada pada halaman utama. Berikut gambar hasil-hasil desain antara lain adalah :

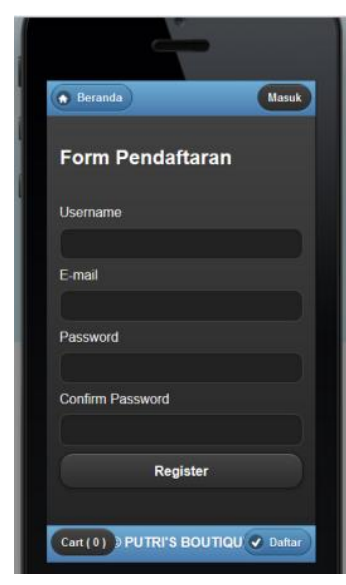

(a)

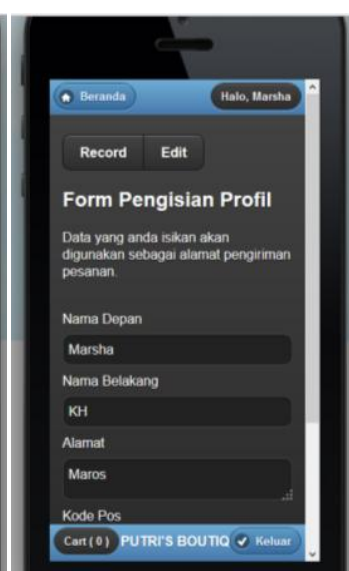

(b)
Gambar 10 (a) Tampilan Menu Daftar (versi mobile)

(b) Tampilan login user untuk pelanggan (versi mobile)

\section{Kesimpulan dan Saran}

Berdasarkan hasil perancangan dan pengujian dengan menggunakan metode blackbox, maka diperoleh sistem mobile web store dengan menggunakan Codeigniter, MysQl, dan jquery mobile. Sistem dapat dijalankan pada perangkat mobile yang memiliki aplikasi browser di dalamnya dan dengan sistem ini dapat memonitoring jumlah penjualan. Sistem dapat ini dapat diintegrasikan dengan sistem lain dengan membangun sistem clien server.

Berdasarkan hasil desain sistem mobile web store dengan menggunakan Codeigniter, MySQL dan jquery mobile dalam penelitian ini, disarankan kepadaaspek keamanan sistem ini dapat dikembangkan dengan menerapkan keamanan yaitu cloud security dan untuk database dengan cloud datatases. Selain itu, penggunaan codeigniter dan jquery mobile dapat ditingkatkan dengan menggunakan framework tersebut dengan versi terbaru.

\section{Daftar Pustaka}

Basuki, Pribadi. 2014. "Proyek Membangun Website Berbasis PHP dengan Codeigniter". Yogyakarta : Badan Penerbit CV. Lokomedia

Raharjo B, Heryanto I, Enjang RK. 2012. "Modul Pemrogamman Web HTML, PHP \& MySQL” Edisi Revisi. Bandung: Modula

Winarno E, Zaki A, Smit, Dev Community. 2014."3 in 1 : Javascript, jQuery dan jQuery Mobile”. Jakarta: Penerbit PT Elex Media Komputindo.

Jogiyanto HM. 2005. "Analisis dan Desain Sistem Informasi", Yogyakarta: Andi Offset

Wardani MK, Putra FN, Jodie R. "Aplikasi BeeLife Berbasis Mobile Web". Jakarta: Universitas Bina Nusantara, 2012

Nugroho, Bunafit. 2008. Aplikasi Pemrogamman Web DInamis dengan PHP dan MySQL. Yogyakarta: Badan Penerbit Gava Media.

Nugroho, Bunafit. 2013. Dasar Pemrogamman Web PHP-MySQL dengan Dreamweaver. Yogyakarta: Badan Penerbit Gava Media.

Paranginan, Kasiman. 2006. Aplikasi Web dengan PHP dan MySQL. Yogyakarta: Andi

Riyanto. 2013. Membangun Mobile Web Store dengan CodeIgniter, MySQL \& jQuery Mobile. Yogyakarta: Badan Penerbit Andi.

Wahan Komputer. 2013. Membuat Sendiri Web Mobile Menggunakan Jquery Mobile. Yogyakarta: Diterbitkan atas kerjasama Penerbit ANDI Yogyakarta dengan Wahana Komputer Semarang 
DINAMIKA Jurnal Ilmiah Teknik Mesin 